Evaluation of the Effectiveness of the Emotional Education Program EMO-ACTION within a Preschool Setting

Evaluación de la eficacia del Programa EMO-ACCIÓN de Educación Emocional para Educación Infantil

MARÍA FERNÁNDEZ-HAWRYLAK

Universidad de Burgos

mfernandez@ubu.es

ORCID 0000-0002-7222-587X

\section{Davinia Heras-Sevilla}

Universidad de Burgos

dheras@ubu.es

ORCID 0000-0002-6337-7476

Abstract: The effectiveness of the Emotional Education Program EMO-ACTION (EMO-ACCIÓN) in the development of emotional skills and emotional strategies is evaluated, as well as empathy and problemsolving skills among preschool students. A sample of 123 children were enrolled in the 2nd year of preschool education, aged between 4 and 5 years old. A design of repeated pre-test/post-test measurements was applied to an experimental group (6o children) and a control group (63 children). The Recognition, Regulation, Empathy and Problem-Solving Scale (RRER) was

\section{Amaya CePa Serano}

Universidad de Burgos

acepa@ubu.es

ORCID 0000-0001-8592-0225 administered before and after the educational intervention. The results confirm that the program had a positive impact on the development of emotional skills in the children that took part in it. A significant increase was noted in emotional recognition, in emotional regulation, and in the identification, and resolution of problems.

Keywords: Program evaluation, Emotional education, Emotional skills, Preschool. 
Resumen: Este trabajo evalúa la eficacia del Programa EMO-ACCIÓN de Educación Emocional en el desarrollo de las competencias y estrategias emocionales, y de las habilidades de empatía o de resolución de problemas en alumnado de Educación Infantil. La investigación cuenta con una muestra de 123 estudiantes de $2^{0}$ curso de Educación Infantil de 4 y 5 años de edad. Se utiliza un diseño de medidas repetidas pre-test/post-test con grupos experimental (6o alumnos) y control (63 alumnos). Se administra antes y después de la intervención educativa la Escala de Reconocimiento, Regulación, Empatía y Resolución de Problemas (RRER). Los resultados obtenidos evidencian que el programa tiene un impacto positivo en el desarrollo de competencias emocionales en el alumnado de Educación Infantil que participa en el mismo. Se produce un incremento significativo en el reconocimiento emocional, en la regulación emocional y en la identificación y resolución de problemas.

Palabras clave: Evaluación de programas, Educación emocional, Competencias emocionales, Educación infantil.

\section{INTRODUCTION}

$\mathrm{R}$ ecognition, comprehension, and the expression of emotions are critical in people's lives, conditioning interpersonal relations, and impacting wellbeing (Fernández-Sánchez, Quintanilla and Giménez-Dasí, 2015). The development of emotional competences is key to children's personality development. Emotional education provides tools and strategies that support higher levels of health, happiness and quality of life (Bisquerra, 2009) and therefore is essential for one's personal, social, family and professional development.

The family is considered the first environment for emotional learning (Gallego-Gil and Gallego-Alarcón, 2004). At its core, intentionally or otherwise, the first emotional learning processes take place within the family. Various works (Abarca, Marzo and Sala, 2002; Fernández-Sánchez, Giménez-Dasí and Quintanilla, 2014; Sadurní and Rostan, 2014), underscore the importance of the period understood between birth and puberty for such development, the first six years of life being fundamental.

School is another important element in the process of emotional development during childhood. It entails an expansion of social relations and the exercise of different social skills closely related with emotional understanding (Denham, Bassett, Brown, Way and Steed, 2015). School therefore represents a fundamental space in the teaching-learning of emotional competences. Works centered on following children from birth to adult, such as those of Layard and Hagell (2015) in the Report on Happiness 2015, illustrated the importance of emotional development as an even more determinant predictor of happiness and subjective wellbeing than academic development. Other investigations centered on schooling (Gil-Olarte, Palomera and Brackett, 2006; Jiménez and López-Zafra, 2009; Pena and Repetto, 2008; Ros, Filella, Ribes and Pérez, 2017) showed the relation between academic performance and self-efficiency within the domain of socio-emotional skills. On 
the whole, special attention has to be given to the emotional development of children. Schools should support the effective management of emotions and how to identify them. In this way, students' will be strengthened, which may increase the capacity to achieve success at adult age (Bernarás, Garaigordobil and de las Cuevas, 2011; Márquez-González, Izal, Montorio and Losada, 2008).

In the Delors Report (Delors, 1996), emotional education is described as an essential complement to cognitive development and a fundamental tool for prevention of psychosocial risks. From this perspective, the promotion and the development of different emotional competences in students, such as identifying and handling emotions, empathy, and problem-solving, will support students to respond appropriately to problematic situations (Grañeras y Parras, 2008; Ruvalcaba, Fernández-Berrocal and Salazar, 2014). It will also help students to avoid risky situations or risk factors and will help them to confront and resolve the challenges of life. These emotional competences occupy a fundamental area for preventive programs for student guidance at school (Grañeras y Parras, 2008; Pérez-González and Pena, 2011). The integral training of a person cannot be understood without an understanding of the emotional development of that person. Schooling has to promote that development, facilitating experiences that mobilize and strengthen competences such as empathy, adaptability, control, and management of emotions, trust in oneself, motivation to work towards the achievement of an objective, persistence in the face of difficulties, problem-solving, skillfulness at negotiating over disagreement, and the potential for leadership, among others (Cepa, 2015; Cepa, Heras and Fernández-Hawrylak, 2017).

Although there is no unanimous agreement about specific contents or competences that should be included in the curriculum, the literature suggests areas that are similar and complementary. Salovey and Sluyter (1997) proposed five dimensions to emotional competence: cooperation, assertiveness, responsibility, empathy, and self-control. Goleman, Boyatzis, and Mckee (2002) presented four areas: selfawareness, self-management, social awareness and relationship management. Cepa (2015), drawing on Bisquerra's work (2009), distinguished four areas or blocks of competences: emotional awareness, emotional regulation, social competence, and life skills for wellbeing. In any case, the need for effective integration of emotional education in the curriculum is now recognized. Scientific and pedagogic interest is now centered on determining how to include emotional education successfully in the classroom. As Pérez-González and Pena (2011) pointed out, it is necessary to study the results of the different programs with some rigor. To that end, various studies have focused on the impact of specific training programs on emotional skills and suggest their positive effect (Celdrán and Ferrándiz, 2012; Maurer and 
Bracket, 2004; Pérez-González, 2012; and Sotil, Escurra, Huerta, Rosas, Campos and Llaños 2008).

In the international context, programs conducted in the United States, under the heading of Social and Emotional Learning (SEL), have produced very promising results, obtaining high developmental levels of emotional competences (Durlak, Weissberg, Dymnicki, Taylor and Schellinger, 2011; Weissberg and O'Brien, 2004). Likewise, Diekstra (2008) conducted an important review on the effectiveness of programs related to emotional and social educational throughout the world, showing a positive impact in the different areas of development and in the wellbeing of the students. Durlak et al. (2011) noted the existence of significant differences in social and emotional competences, in attitudes, in behavior and in academic performance among students that had participated in the programs versus their classmates from the control group.

In Spain, where this evaluation was carried out, there have been few investigations on the impact of programs of emotional education at different educational stages. Some studies have been conducted within the context of elementary education (Agulló, Filella, Soldevila and Ribes, 2011; Ambrona, López-Pérez and Márquez-González, 2012; Benito, 2017; Filella-Guiu, Pérez-Escoda, Agulló and Oriol, 2014; Merchán, Bermejo and González, 2014; Sotil et al., 2008; Tur, Mestre, Samper, Malonda and Llorca, 2014), and in secondary education (Obiols, 2005; Olmedo, del Barrio and Santed, 2003; Pascual and Cuadrado, 2001).

However, studies on emotional education within the preschool context are scarce (Alba Corredor, Justicia-Arráez, Pichardo and Justicia, 2013; FernándezSánchez et al., 2014; Fernández-Sánchez et al., 2015 Giménez-Dasí and Quintanilla, 2009; Cepa et al., 2017; Justicia-Arráez, Pichardo and Justicia, 2015; LópezCassá, 2005). One of the reasons that may explain this scarcity is the inexistence of validated evaluation instruments that have been adapted to the level of emotional development of preschool students. As a result, Johnson, Finlon and Izard (2016) claimed the need to validate tools for the evaluation of social and emotional competences among preschool children. They proposed the Behavior and Emotion Expression Observation System to Characterize Preschoolers' Social and Emotional Interactions (BEEOS). In essence, there is a marked concern for the education of emotions at early ages, but insufficient empirical evidence.

The design and application of educational programs for the evaluation of emotional education, the objective of which is to develop emotional competences, will never be sufficient, without having to evaluate the interventions, to gather empirical data on the degree of validity and to detect aspects that are susceptible to improvement (Bisquerra, 2006; Bisquerra, 2012; Pérez-González and Pena, 2011). 
Given the convenience of starting with emotional education in preschool education, as well as the need to contribute rigorous results in this field, the objective of this investigation was to design and evaluate an Emotional Education Program for the second cycle of early schooling. This paper provides an evaluation of its impact on the development of the emotional competences of children between 4 and 5 years old.

\section{The EMO-ACTION Program}

The Emotional Education program EMO-ACTION was designed and developed for the 2 nd year of preschool education. This program incorporates the recommendations from López-Cassá (2003), and Pérez-González and Pena (2011), principally based on the theoretical model of Bisquerra (2009). The objective of the EMO-ACTION program is for students to develop emotional strategies and empathetic and conflict-resolution skills, supporting the integral development of children's personality, and providing information about possible risk factors.

The program is divided into four thematic units, in accordance with the development of the participants. These units are designed in a sequential manner, so as to introduce basic, complex, and ambiguous emotions in a progressive manner. Educational programs of relevance were taken into account (Ibarrola, 2004; López-Cassá, 2003; Lozano and Alcaraz, 2009; Monjas, 2018; Vallés, 2000), for defining the content and the activities.

The four units that comprised the program responded to different dimensions of emotional competence, developed in activities, workshops, and games. They all begin with centers of interest for the students and situations from daily life. Both significant and independent learning are encouraged, as well as cooperative and socializing experiences.

The first unit, Emotional awareness, is centered on the identification, expression, and recognition of various emotions. It seeks awareness of one's own and other people's emotions, as well as reflection upon them.

The second unit, Emotional regulation, targets emotional management and the prevention of prejudicial effects arising from unacceptable management of negative emotions. Among the elements of this unit, two stand out: the identification of situations of aggressiveness and anger, and control of impulsiveness and waiting times.

The objective of the third unit, Emotional independence, is to strengthen the expression of basic qualities of oneself. It also focuses on acceptance of responsibilities, as well as eliminating negative verbalizations about oneself. The concept of self and self-esteem are essential aspects in this block. 
Finally, block four, Socio-emotional skills and life skills, focuses on empathy and interpersonal problem-solving. Children analyze various situations in a cooperative way and reflect on emotions (their own and others' emotions), interpersonal problems, and their possible solutions.

\section{METHOD \\ Participants}

The sample comprised 123 students aged between 4 and 5 years old (mean $=50.67$ months, S.D.=3.23), 61 of whom were boys (51.8\%) and 62 girls (48.2\%). All of them were in their 2 nd year of preschool education at a public center for Preschool and Primary Education (Centro público de Enseñanza Infantil y Primaria, CEIP) in the autonomous community of Castile and León in northwestern Spain. The school is a preferential center for students with motor disabilities. A convenience non- probabilistic sampling method was used for the selection of the center (Hernández, Fernández and Baptista, 2014), considering intentional criteria such as the large size of the center and therefore of the sample size.

As the Educational Project of the school reflected, the characteristics of the selected center were multiple and plural. The students were organized into six classrooms, and the educational center determined which classrooms were part of the experimental or the control group, in order to avoid that the distribution corresponded with the research interests and seeking that both groups had similar characteristics.

The experimental group comprised 60 participants $(M=50.67$ months, $S D=$ 3.33 ) and the control group comprised $63(M=50.68$ months, $S D=3.18)$. The distribution of the sample by sex was uniform both in the experimental (29 boys and 31 girls) and in the control group ( 32 boys and 31 girls). Twelve students with specific educational support needs were part of the experimental group, and 10 of the control group (Cepa et al., 2017).

\section{Instruments}

The instrument used for the evaluation of the program in both the pre-test and the post-test was the Escala de Reconocimiento, Regulación, Empatía y Resolución de Problemas (RRER) [Recognition, Regulation, Empathy and Problem-Solving Scales] (Cepa, 2015), designed for measurement of levels of emotional competence among children aged between 45 and 60 months. The scale evaluates the capability of 
the child to recognize and to express emotions (emotional awareness), to regulate emotions (emotional regulation), to place oneself in another person's position (social competence), and to identify and to solve problems (life skills for wellbeing).

The RRER has 5 sub-scales of emotional competence. The first one, "Recognition of emotions through pictures and photographs" (RED), has 15 items presented by 4 images (pictures or photographs). The child must point out the image that correspond to the emotion that the examiner enunciates (Figure 1). The second sub-scale, "Recognition of emotions through contextual situations" (RECS) has 15 items, each one presenting a real-life scenario, and four facial alternatives expressing different emotions. The child must point out the face that better suits the situation that the examiner presents verbally (Figure 2). The third sub-scale, "Emotional regulation" (EREG); has 15 items related to impulsivity control, anger management and waiting times. Two cards are given to the child and he/she is asked to select which one matches up with his/her behavior (Figure 3). The fourth sub-scale, "Empathy" (EMP), has 10 items that represent different situations. The child must choose between two alternatives verbally presented by the examiner (Figure 4). Finally, the "Identification and problem-solving" sub-scale (IREP) has 5 items that show problematic situations. The assessment is composed of two different sections, identification of the problem and its resolution (Figure 5).

In the present study, the RRER indicated excellent internal consistency, $(\alpha=$ $.865 ; \Omega=.885)$. The reliability found in each of the sub-scales was also good: (1) $\operatorname{RED}(\alpha=.748 ; \Omega=.755),(2) \operatorname{RESCs}(\alpha=.702 ; \Omega=.775),(3) \operatorname{REG}(\alpha=.705 ; \Omega=.778)$, (4) $\operatorname{EMP}(\alpha=.758 ; \Omega=.788)$, and (5) IREP $(\alpha=.760 ; \Omega=.841)$.

Figure 1. RED subscale, item 3
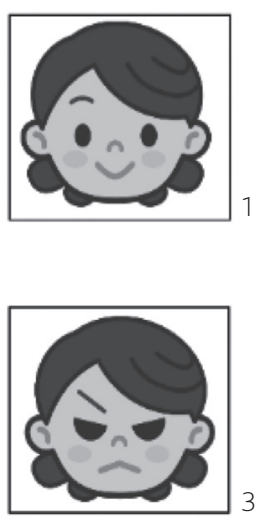
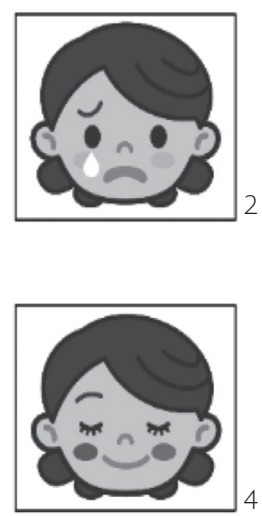

Figure 2. RESC subscale, item 2
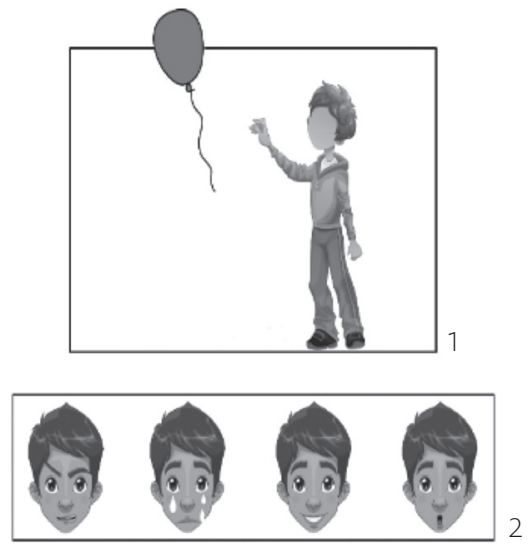
Figure 3. REG subscale, item 4
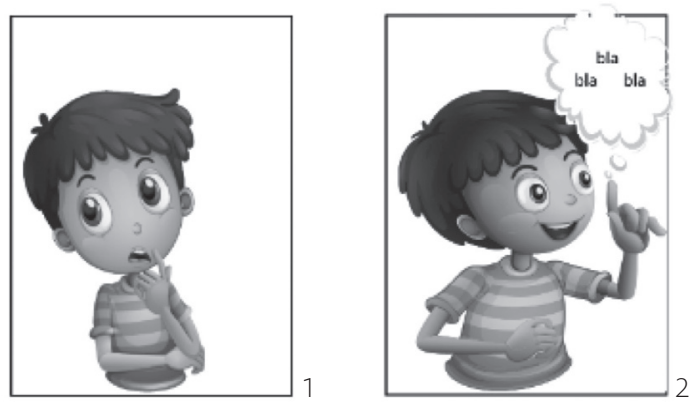

Figure 4. EMP subscale, item 8

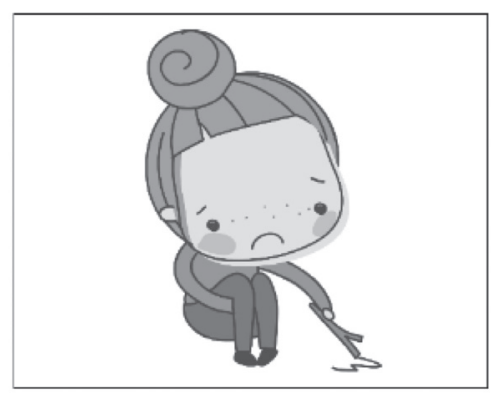

Figure 5. IREP subscale, item 4

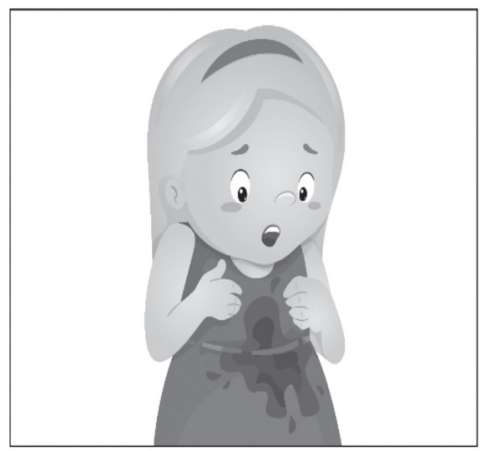

\section{Procedure}

A quasi-experimental design was conducted to determine the effectiveness of the EMO-ACTION, program, with two groups of subjects. The first, the experimental group, was comprised of students who had participated in the program. The second, the control group, was comprised of children who had not experienced the program.

The collection of data, both pre- and post-intervention was done individually at the educational center, using the instrument described above, after having sought the informed consent of the children's parents or guardians.

\section{Data analysis}

Following data collection, the data were organized, codified, and analyzed with the SPSS statistical software package, version 23.0. The analysis principally consisted 
of a comparison between pre-intervention and post-intervention measurements, both for the experimental and for the control group. On finding a normal distribution, the Wilcoxon signed-ranked test was applied, evaluating the effect size with Hedge's g statistic.

\section{RESULTS}

The results obtained on the RRER scale and in the five sub-scales, both for the experimental and for the control group, are presented below. Table 1 shows the scores obtained by both groups in the pre-test and in the post-test. In the experimental group, the global level of emotional competence before the educational intervention fluctuated between 21 and 56, with an average of $41.28(S D=7.99)$. In the control group, the range of scores for prior emotional intelligence was higher, fluctuating between 13 and 59. The mean in this case was notably higher $(M=$ 42.92, DT = 9.13), without finding statistically significant differences between both groups. In the same way as for the global level of emotional competence, the scores were similar in the different sub-scales, for the experimental and for the control group. Those scores were noticeably higher in the control group, except for the recognition of emotions through contextual situations (RECS). In the pre-test, averages of $7.10(S D=1.89)$ and $7.01(S D=2.28)$ were obtained by the experimental and the control groups, respectively. The tendency was inverted in the posttest where the global level of emotional competence in the experimental group $(M=59.90, S D=3.93)$ was greater than in the control group $(M=41.93, S D=6.71)$. The students from the group that had received the training obtained higher scores on all sub-scales.

Pre- and post-intervention measurements were compared to determine the impact of the EMO-ACTION program and to assess the noticeable increase in the scores obtained by the experimental group. The signed-rank test of Wilcoxon was applied to both sets of measurements (Table 2). The scores of the post-test of the global level of emotional competences $(p=.000)$ increased in a significant manner in the experimental group. In addition, the high effect size that was noted $(\delta=$ 2.94), indicates the high effectiveness the EMO-ACTION program. In the control group, on the contrary, a slight decrease was observed in the emotional competences, although it was of no significance $(p=.256)$. In this case, the effect size was low $(\delta=-.12)$, showing a limited or non-existent increase of emotional competences, before having participated in the EMO-ACTION program.

In relation to the sub-scales that comprise the RRER, the comparison between scores obtained in both the pre-test and the post-test by the experimental 
group reveals significant differences in all of them $(p=.000)$. A statistically significant increase $(p=.000)$ is observed in recognition of emotions for the first sub-scale, through drawings and photographs (RED), after the application of the EMO-ACTION program, with a high effect size $(\delta=1.50)$, which is evidence of a significant improvement. In the control group, on the contrary, a significant reversal or impasse occurred between the pre-test and the post-test $(p=.000)$, with a good effect size $(\delta=-.92)$.

In the case of recognition of emotions in contextual situations in the second sub-scale (RECS), the evolution in the experimental group was positive and statistically significant $(Z=-6.70 ; p=.000)$, with an excellent effect size $(\delta=3.08)$. In the control group, although there is also a positive trend, no significant differences were evident between the pre-test and the post-test $(p=.303)$, with hardly any effect size $(\delta=.18)$.

Similar results were found on the sub-scale for emotional regulation (REG). The experimental group saw a statistically significant increase in the score $(p=.000)$ with a high effect size $(\delta=1.89)$. In the case of the control group, there was no positive increase of emotional regulation and there were no statistically significant differences $(p=.682)$.

Over the course of time, both groups improved on the empathy sub-scale (EMP). In the case of the experimental group, the difference between the score obtained in the pre-test and the post-test was statistically significant $(p=.000)$, with a high effect size $(\delta=2.24)$. A significant increase in empathy in the post test among the students in the control group was also evident $(p=.036)$; however, the effect size was not high $(\delta=.29)$.

Finally, the experimental group achieved higher scores in the post-test on the sub-scale of problem identification and problem solving (IREP). Among those who participated in the EMO-ACTION program, the trends were statistically significant $(p=.000)$, with an effect size that suggests the effectiveness of the program $(\delta=$ 1.54). There were no significant differences at all in the post-test $(p=.214)$ for the control group, with a slight effect size $(\delta=-.18)$.

The results showed a statistically significant $(p<.01)$ improvement in the experimental group, attributable to the EMO-ACTION program, at the global level of emotional competences and on all five sub-scales and with a high effect size $(\delta>1.50)$. The slow development and even the loss of emotional competences of the control group is worth noting, with a slight increase occurring only for empathy $(p<.05)$. The EMO-ACTION program, therefore, not only supports children's emotional development, but provides an opportunity connect these competences. It is worth noting that the young children of the ex- 
perimental group, in relation to the control group, demonstrated lower levels of competence in the pre-test, except in the recognition of emotions in contextual situations (RECS). Taking into account the effect sizes found, these results suggests that the EMO-ACTION program support the development of emotional competences to a significant extent.

Table 1. Descriptive statistics of emotional competences

\begin{tabular}{|c|c|c|c|c|c|c|c|c|c|c|c|c|c|c|c|}
\hline & \multicolumn{8}{|c|}{ PRE-TEST } & \multicolumn{6}{|c|}{ POST-TEST } \\
\hline & & MíN. & MÁX. & AVG. & SD & Q1 & Q2 & Q3 & MíN. & MÁX. & AVG. & SD & Q1 & Q2 & Q3 \\
\hline \multirow{6}{*}{$\begin{array}{l}\text { Experimental } \\
\text { group } \\
(n=60)\end{array}$} & RRER & 21 & 56 & 41.28 & 7.99 & 36 & 42 & 47 & 37 & 63 & 59.90 & 3.93 & 59.25 & 61 & 62 \\
\hline & RED & 6 & 15 & 11.60 & 2.49 & 10 & 12 & 13 & 11 & 15 & 14.40 & .82 & 14 & 15 & 15 \\
\hline & RESC & 2 & 11 & 7.10 & 1.89 & 6 & 7 & 8 & 10 & 14 & 11.75 & .96 & 11 & 12 & 12 \\
\hline & REG & 4 & 15 & 10.43 & 2.71 & 9 & 11 & 12 & 5 & 15 & 14.54 & 1.41 & 15 & 15 & 15 \\
\hline & EMP & 0 & 10 & 5.55 & 2.09 & 4 & 5.5 & 7 & 0 & 10 & 9.56 & 1.39 & 10 & 10 & 10 \\
\hline & IREP & 0 & 10 & 6.60 & 2.58 & 5 & 7 & 8.75 & 6 & 10 & 9.60 & .90 & 10 & 10 & 10 \\
\hline \multirow{6}{*}{$\begin{array}{l}\text { Control } \\
\text { group } \\
(n=63)\end{array}$} & RRER & 13 & 59 & 42.92 & 9.13 & 37 & 45 & 49 & 24 & 55 & 41.93 & 6.71 & 38 & 43 & 45 \\
\hline & RED & 5 & 15 & 12.09 & 2.13 & 11 & 12 & 13 & 5 & 15 & 10.14 & 2.07 & 9 & 10 & 11 \\
\hline & RESC & 0 & 10 & 7.01 & 2.28 & 6 & 7 & 9 & 3 & 10 & 7.36 & 1.62 & 7 & 8 & 8 \\
\hline & REG & 0 & 15 & 10.90 & 2.99 & 9 & 11 & 13 & 5 & 15 & 10.90 & 2.15 & 9 & 11 & 12 \\
\hline & EMP & 0 & 10 & 6.17 & 2.46 & 4 & 6 & 8 & 2 & 10 & 6.84 & 2.04 & 6 & 7 & 9 \\
\hline & IREP & 0 & 10 & 7.07 & 2.21 & 6 & 7 & 9 & 0 & 10 & 6.68 & 2.17 & 5 & 7 & 9 \\
\hline
\end{tabular}


Table 2. Comparison of emotional competences between the pre-test and the post-test

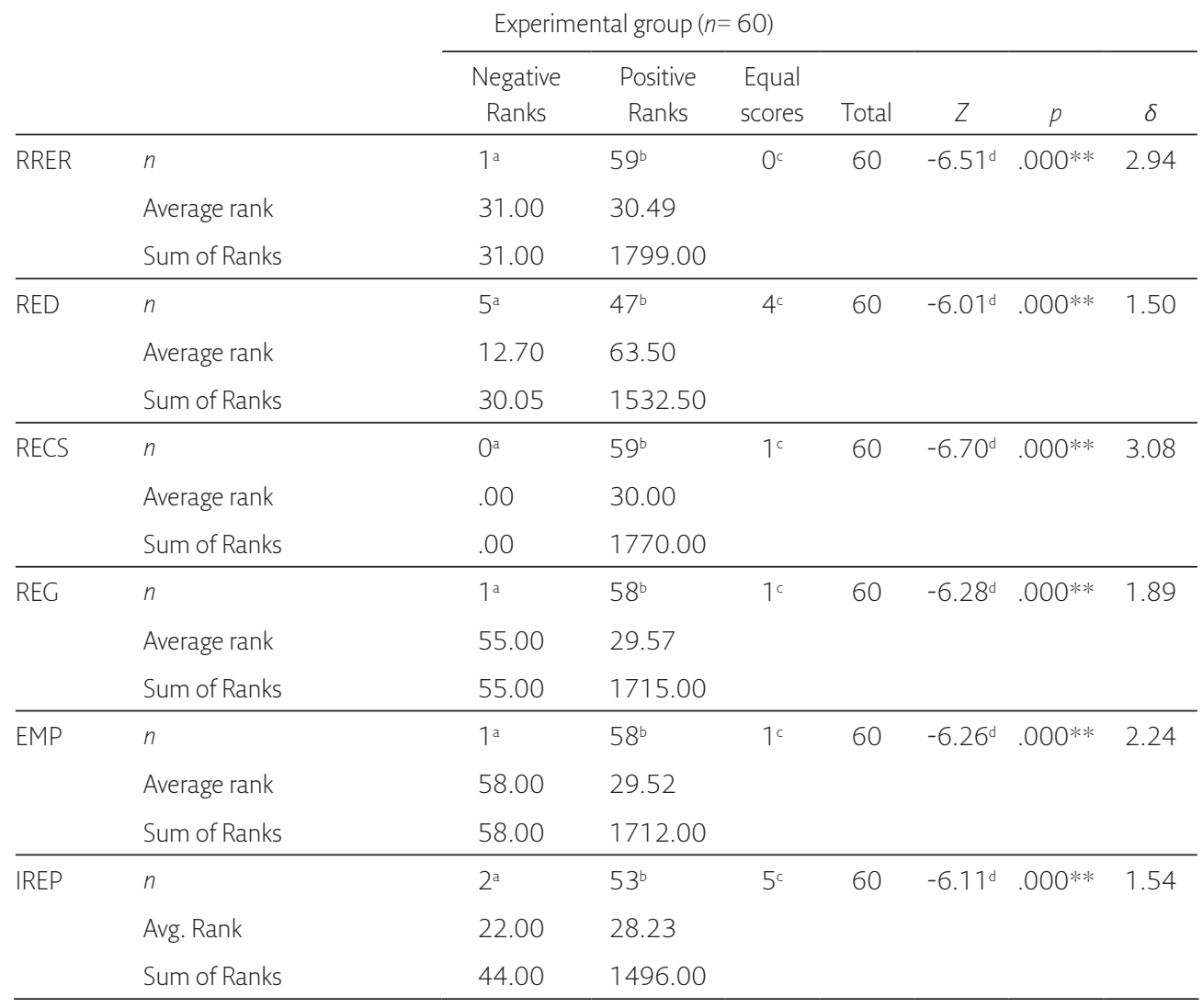

[CONTINUED ON NEXT PAGE] 
EVALUATION OF THE EFFECTIVENESS OF THE EMOTIONAL EDUCATION PROGRAM EMO-ACTION

Table 2. Comparison of emotional competences between the pre-test and the post-test

\begin{tabular}{|c|c|c|c|c|c|c|c|c|}
\hline & & Contro & oup $(n=63$ & & & & & \\
\hline & & $\begin{array}{l}\text { Negative } \\
\text { Ranks }\end{array}$ & $\begin{array}{c}\text { Positive } \\
\text { Ranks }\end{array}$ & $\begin{array}{l}\text { Equal } \\
\text { scores }\end{array}$ & Total & Z & p & $\delta$ \\
\hline RRER & $n$ & $34^{a}$ & $27^{b}$ & $0^{c}$ & 61 & $-1.13^{e}$ & .256 & -.12 \\
\hline & Average rank & 34.56 & 29.17 & & & & & \\
\hline & Sum of Ranks & 1103.50 & 787.00 & & & & & \\
\hline RED & $n$ & $47^{a}$ & $8^{b}$ & $8^{c}$ & 63 & $-5.09^{e}$ & $.000 * *$ & -.92 \\
\hline & Average rank & 29.20 & 20.94 & & & & & \\
\hline & Sum of Ranks & 1372.50 & 167.50 & & & & & \\
\hline RECS & $n$ & $23^{a}$ & $27^{b}$ & $13^{c}$ & 63 & $-1.03^{d}$ & .303 & .18 \\
\hline & Average rank & 23.13 & 27.52 & & & & & \\
\hline & Sum of Ranks & 532.00 & 743.00 & & & & & \\
\hline REG & $n$ & $32^{\mathrm{a}}$ & $25^{b}$ & $4^{c}$ & 61 & $-0.41^{e}$ & .682 & .00 \\
\hline & Average rank & 27.42 & 31.02 & & & & & \\
\hline & Sum of Ranks & 877.50 & 775.50 & & & & & \\
\hline EMP & $n$ & $19^{a}$ & $36^{b}$ & $8^{c}$ & 63 & $-2.09^{d}$ & $0.036 *$ & .29 \\
\hline & Average rank & 27.47 & 28.28 & & & & & \\
\hline & Sum of Ranks & 522.00 & 1018.00 & & & & & \\
\hline IREP & $n$ & $32^{\mathrm{a}}$ & $20^{\mathrm{b}}$ & $11^{c}$ & 63 & $-1.24^{e}$ & .214 & -.18 \\
\hline & Avg. Rank & 25.75 & 27.70 & & & & & \\
\hline & Sum of Ranks & 824.00 & 554.00 & & & & & \\
\hline
\end{tabular}

${ }^{*} p<.05^{* *} p<.01$

a. The scores for emotional competences in the post-test < the score for emotional competences in the pre-test.

b. The scores for emotional competences in the post-test $>$ the score for emotional competences in the pre-test.

c. The scores for emotional competences in the post-test= the score for emotional competences in the pre-test.

d. Based on positive ranks.

e. Based on negative ranks. 


\section{DISCUSSION}

This investigation shows the evolution of emotional competences of students in preschool education who have participated in the EMO-ACTION program. This implies an advance in itself, given the scarcity of research on the evaluation of emotional education programs in early childhood education (Alba Corredor et al., 2013; Fernández-Sánchez et al., 2014; Fernández-Sánchez et al., 2015; GiménezDasí and Quintanilla, 2009; Justicia-Arráez et al., 2015; López-Cassà, 2005).

In addition, the results show a sizeable increase in global emotional competences. This improvement in the general level of competence was also found in previous studies completed with students in primary education, both with children in early grades (aged between 5 and 7 years old) (Celdrán and Ferrándiz, 2012; Merchán et al., 2014), and in the later ones (aged between 8 and 12 years old) (Benito, 2017; Sotil et al., 2008).

The development in emotional recognition, as a component of emotional competence, was also evaluated in this work. The students who experienced the EMOACTION program progressed in a significant manner with the identification of emotions, both in drawings and in contextual situations. Fernández-Sánchez et al. (2015), in a study completed with 57 boys and girls between 21 and 32 months, found a significant improvement in emotional knowledge in the children who participated in their educational program. Other studies completed in the Spanish context (Agulló et al., 2011; Ambrona et al., 2012; Celdrán and Ferrándiz, 2012), suggested similar results in older students in primary education, with ages between 6 and 10 years old. However, this study reveals a significant reversal of emotional recognition in drawings and photographs among students who were not participating in the program. The greater presence of students with Autism Spectrum Disorder (ASD) in the control group might explain this reversal. As Miguel (2006) indicated, children with ASD are often unable to interpret feelings in facial gestures, a crucial aspect for successful responses to this sub-scale. It also justifies why there was no reversal in emotional recognition in contextual situations, as every situation was preceded by an explanation that facilitated its interpretation.

In this study, a differential tendency was discovered in the competence to recognize emotions in accordance with the input that was presented (drawings/ photographs or contextual situations). It was confirmed in all the measurements that the scores obtained for the unit of contextual situations were lower than those obtained in the unit of drawings and photographs. These results were similar to the findings of Cano (2010) who studied adults and noted higher emotional recognition through images. On the contrary, greater recognition in the unit of contextual 
situations was found in Celdrán and Ferrándiz's work (2012) with children aged between 6 and 7 years old. These results indicate that other cognitive and interpretative processes intervene both in the skill of recognizing emotions in faces and in the capability of interpreting emotions, which should be given more in-depth study.

Given the importance that control over emotions has on children's emotional development and its beneficial effects on social functioning and on emotional wellbeing (Little, Kluemper, Nelson and Gooty, 2011; Niven, Totterdell and Holman, 2007; Rimé, 2012), children's development of emotional regulation was studied. The results provided evidence that the students who participated in the program acquired high levels of emotional regulation; a notable point given the potential for self-protection of that competence. Similarly the present study, Filella-Guiu et al. (2014) found an important improvement in emotional regulation between students from the first stage of primary education (ages 6-to- 8 years old) that experienced their emotional education intervention.

With regard to empathy, this study has found evidence of the maturity factor associated with its development. Nevertheless, given the high effect size, the students participating in the program deepened their maturity to a greater extent. Moreover, the study completed by Merchán et al. (2014) with children aged between 5 and 7 years old revealed a higher impact of educational programs on empathy. Other studies carried out with older students (aged between 10 and 19 years old) revealed the impact of empathy programs as well (Garaigordobil and García, 2006; Mestre, Samper, Frías and Tur 2009; Sánchez-Queija, Oliva and Parra, 2006).

The results obtained in this research demonstrated a significant increase in the identification and solution of problems among students who participated in the EMO-ACTION program. Greenberg, Domitroich, and Bumbarger (2000) found similar results with students who participated in the program I Can Solve Problems (ICPS), noting a significant improvement in their problem-solving capability.

The EMO-ACTION program can be useful as a preventive measure, in response to the appearance of risk factors such as aggressive and disruptive behavior in the classroom. As with other programs such as Aprender a Convivir [Learn to Live Together] (Alba Corredor et al., 2013), Enseñanza de Habilidades de Interacción Social: PEHIS [Teaching of Social Interactive Abilities] (Monjas, 2018) and Filosofía para niños [Philosophy for Children] (Giménez-Dasí and Quintanilla, 2009), this program helps children acquire a wide repertoire of emotional skills that favor and facilitate future social adjustment.

The absence of a standardized instrument to measure emotional competence at early ages implies a limitation, both for the evaluation of the program and its subsequent comparison with previous investigations. This limitation was previ- 
ously underscored in the work of Johnson et al. (2016) with 148 preschool students. Nevertheless, the creation of an RRER scale has made a rigorous and effective evaluation of the program possible.

The EMO-ACTION program is effective for the development and reinforcement of different emotional competences with students of 4 and 5 years old. It presents great potential for application in schools. As a line of future investigation, it needs follow up and a long-term evaluation, in order to conduct a deeper study of the progress of the different emotional competences. It would also be appropriate to replicate this study in other contexts, such as rural areas and in schools with students with special needs for educational support (Cepa et al., 2017); controlling especially for the presence of students with ASD. In any case, the present work endorses the effectiveness of emotional education, even though the study is time bound and limited to a single educational center, which is the main limitation of quasi-experimental research.

This work has justified the pertinence of programs that support students' emotional development and demonstrates their effectiveness for the development and consolidation of emotional competences, particularly as part of the curriculum. These strategies and skills have to be nurtured, given that they are essential for life and are closely related to subjective wellbeing, health and quality of life (Bisquerra, 2009, Fernández-Sánchez et al., 2015). In sum, such programs provide a response to the challenge of providing a holistic and integral approach to education.

Fecha de recepción del original: 7 de febrero 2019

Fecha de aceptación de la versión definitiva: 2 de mayo 2020

\section{REFERENCES}

Agulló, M. J., Filella, G., Soldevila, A. and Ribes, R. (2011). Evaluación de la educación emocional en el ciclo medio de Educación Primaria. Revista de Educación, 354, 347-349.

Alba Corredor, G. A., Justicia-Arráez, A., Pichardo, M. C. and Justicia, F. (2013). Aprender a Convivir. Un programa para la mejora de la competencia social del alumnado de Educación Infantil y Primaria. Electronic fournal of Research in Educational Psychology, 11(3), 883-904.

Ambrona, T., López-Pérez, B. and Márquez-González, M. (2012). Eficacia de un programa de educación emocional breve para incrementar la competencia emocional de niños de educación primaria. Revista Española de Orientación y Psicopedagogía, 23(1), 39-49. 
Benito, S. C. (2017). Diseño, desarrollo y evaluación del programa "Vera" de educación emocional en la etapa de educación primaria (Doctoral Thesis, Universidad Nacional de Educación a Distancia).

Bernarás, E., Garaigordobil, M. and de las Cuevas, C. (2011). Inteligencia emocional y rasgos de personalidad. Influencia de la edad y el género durante la edad adulta y la vejez. Boletín de Psicología, 103, 75-88.

Bisquerra, R. (2006). Orientación psicopedagógica y educación emocional. Estudios sobre Educación, 11, 9-25.

Bisquerra, R. (2009). Psicopedagogía de las emociones. Madrid: Síntesis.

Bisquerra, R. (Coord.) (2012). ¿Cómo educar las emociones? La inteligencia emocional en la infancia y la adolescencia. Esplugues de Llobregrat: Hospital Sant Joan de Déu.

Cano, M. (2010). Reconocimiento de estados básicos y complejos a partir de indicios faciales y contextuales. Evaluación y optimización de procesos intelectuales implicados en la sensibilidad interpersonal (Doctoral Thesis, Universidad Autónoma de Barcelona).

Celdrán, J. and Ferrándiz, C. (2012). Reconocimiento de emociones en niños de Educación Primaria: Eficacia de un programa educativo para reconocer emociones. Electronic Fournal of Research in Educational Psychology, 10(3), 1321-1342.

Cepa, A. (2015). Diseño, Aplicación y Evaluación del Programa "EMO-ACCIÓN" de Educación Emocional para Educación Infantil (Doctoral Thesis, Universidad de Burgos).

Cepa, A., Heras, D. and Fernández-Hawrylak, M. (2017). La educación emocional en la infancia: una estrategia inclusiva. Aula Abierta, 46, 73-82.

Delors, J. (1996). Los cuatro pilares de la educación. In La educación encierra un tesoro. Informe a la UNESCO de la Comisión internacional sobre la educación para el siglo XXI (pp. 91-103). Madrid: Santillana/UNESCO.

Denham, S. A., Bassett, H. H., Brown, C., Way, E. and Steed, J. (2015). "I Know How You Feel": Preschoolers' emotion knowledge contributes to early school success. Fournal of Early Childhood Research, 13(3), 252-262.

Diekstra, R. F. W. (2008). Evaluación de los programas escolares universales de educación emocional y social y de habilidades para la vida. In C. Clouder (Dir.), Educación emocional y social. Análisis internacional (pp. 269-329). Santander: Fundacion Marcelino Botín.

Durlak, J. A., Weissberg, R. P., Dymnicki, A. B., Taylor, R. D. and Schellinger, K. R. (2011). The impact of enhancing students' social and emotional learning: A meta-analysis of school-based universal interventions. Child Development, 82(1), 405-432. 
Fernández-Sánchez, M., Giménez-Dasí, M. and Quintanilla, L. (2014). La comprensión temprana de las emociones básicas: Identificación, etiquetado y causalidad. Infancia y Aprendizaje, 37(3), 569-601.

Fernández-Sánchez, M., Quintanilla, L. and Giménez-Dasí, M. (2015). "Pensando las emociones" con niños de dos años: un programa educativo para mejorar el conocimiento emocional en primer ciclo de Educación Infantil. Cultura y Educación, 27(4), 819-838.

Filella-Guiu, G., Pérez-Escoda, N., Agulló, M. and Oriol, X. (2014). Resultados de la aplicación de un programa de educación emocional en Educación Primaria. Estudios sobre Educación, 26, 125-147.

Garaigordobil, M. and García, P. (2006). Empatía en niños de 10 a 12 años. Psicothema, 18(2), 180-186.

Gallego-Gil, D. J. and Gallego-Alarcón, M. J. (2004). Educar la inteligencia emocional en el aula. Madrid: PPC.

Gil-Olarte, P., Palomera, R. and Brackett, M.A. (2006). Relating emotional intelligence to social competence, and academic achievement among high school students. Psicothema, 18(supl.), 118-123.

Giménez-Dasí, M. and Quintanilla, L. (2009). "Competencia” social, "competencia” emocional: una propuesta para intervenir en Educación Infantil. Infancia y Aprendizaje, 32(3), 359-373.

Goleman, D., Boyatzis, R. and McKee, A. (2002). El líder resonante crea más. El poder de la inteligencia emocional. Barcelona: Plaza \& Janés.

Grañeras, M. and Parras, A. (Coords.) (2008). Orientación educativa: fundamentos teóricos, modelos institucionales y nuevas perspectivas. Madrid: Centro de Investigación y Documentación Educativa - CIDE.

Greenberg, M. T., Domitrovich, C. D. and Bumburger, B. (2000) Preventing mental disorders in school-age children: A review of the effectiveness of prevention programs. Retrieved from website of Pennsylvania State University http://scripts.cac.psu.edu/dept/prevention/CMHS.PDF

Hernández, R., Fernández, C. and Baptista, P. (2014). Metodología de la Investigación. México: Mc. Graw Hill.

Ibarrola, B. (2004). Sentir y pensar: programa de Inteligencia Emocional para niños de 3-5 años. Madrid: SM.

Jiménez, M. I. and López-Zafra, E. (2009). Inteligencia emocional y rendimiento escolar: Estado actual de la cuestión. Revista Latinoamericana de Psicología, 41(1), 69-79.

Johnson, S. R., Finlon, K. J. and Izard, C. E. (2016). The Development and Validation of the Behavior and Emotion Expression Observation System to Char- 
acterize Preschoolers' Social and Emotional Interactions. Early Education and Development, 27(7), 896-913.

Justicia-Arráez, A., Pichardo, C. and Justicia, F. (2015). Efecto del programa Aprender a Convivir en la competencia social y en los problemas de conducta del alumnado de 3 años. Anales de Psicología, 31(3), 825-836.

Layard, R. and Hagell, A. (2015). Healthy young minds: Transforming the mental health of children. In J. Helliwell, R. Layard and J. Sachs (Eds.), World Happiness Report 2015 (pp. 106-130). New York: Sustainable Development Solutions Network.

Little, L. M., Kluemper, D., Nelson, D. L. and Gooty, J. (2011). Development and validation of the Interpersonal Emotion Management Scale. Fournal of Occupational and Organizational Psychology, 85(2), 407-420.

López-Cassà, E. (Coord.) (2003). Educación emocional. Programa para 3-6 años. Barcelona: Praxis.

López-Cassà, E. (2005). La educación emocional en la educación infantil. Revista Interuniversitaria de Formación del Profesorado, 19(3), 153-167.

Lozano, J. and Alcaraz, S. (2009). Aprende con Zapo. Propuestas didácticas para el aprendizaje de habilidades emocionales y sociales. Madrid: Wolters Kluwer.

Marzo, L., Sala, J. and Abarca, M. (2002). La educación emocional en la práctica educativa de Primaria. Bordón, 54(4), 505-518.

Márquez-González, M., Izal, M., Montorio, I. and Losada, A. (2008). Experiencia y regulación emocional a lo largo de la etapa adulta del ciclo vital: análisis comparativo en tres grupos de edad. Psicothema, 20(4), 616-622.

Maurer, M. and Brackett, M. A. (2004). Emotional literacy in the middle school. A 6-step program to promote social, emotional, and academic learning. New York: Dude.

Merchán, I. M., Bermejo, M. L. and González, J. D. (2014). Eficacia de un Programa de Educación Emocional en Educación Primaria. Revista de Estudios e Investigación en Psicología y Educación, 1(1), 91-99.

Mestre, M. V., Samper, P., Frías, M. D. and Tur, A. M. (2009). ¿Son las mujeres más empáticas que los varones? Un estudio longitudinal en la adolescencia. Spanish Fournal of Psychology, 12(1), 76-83.

Miguel, A. M. (2006). El mundo de las emociones en los autistas. Teoría de la Educación: Educación y Cultura en la Sociedad de la Información, 7(2), 169-183.

Monjas, M. I. (2018). Programa de Enseñanza de Habilidades de Interacción Social (PEHIS). Madrid: CEPE.

Niven, K., Totterdell, P. and Holman, D. (2009). A classification of controlled interpersonal affect regulation strategies. Emotion, 9(4), 498-509. 
Obiols, M. (2005). Diseño, desarrollo y evaluación de un programa de educación emocional en un centro educativo. Revista Interuniversitaria de Formación del Profesorado, 19(3), 137-152.

Olmedo, M., del Barrio V. and Santed, M. A. (2003). Eficacia de un programa preventivo de problemas emocionales en adolescentes en función del rendimiento académico. Acción Psicológica, 2(3), 213-222.

Pascual, V. and Cuadrado, M. (Coords.) (2001). Educación emocional: programa de actividades para Educación Secundaria Obligatoria. Barcelona: CISSPraxis.

Pena, M. and Repetto, E. (2008). Estado de la investigación en España sobre Inteligencia Emocional en el ámbito educativo. Revista Electrónica de Investigación Psicoeducativa, 6(2), 400-420.

Pérez-González, J. C. (2012). Revisión del aprendizaje social y emocional en el mundo. In R. Bisquerra (Ed.). (Coord.), ¿Cómo educar las emociones? La inteligencia emocional en la infancia y la adolescencia (pp. 56-69). Esplugues de Llobregat: Hospital Sant Joan de Déu.

Pérez-González, J. C. and Pena, M. (2011). Construyendo la ciencia de la educación emocional. Revista Padres y Maestros, 342, 32-35.

Rimé, B. (2012). La compartición social de las emociones. Bilbao: Desclée de Brouwer. Ros, A., Filella, G., Ribes, R. and Pérez, N. (2017). Análisis de la relación entre competencias emocionales, autoestima, clima de aula, rendimiento académico y nivel de bienestar en una muestra de escolares de educación primaria. $R e-$ vista Española de Orientación y Psicopedagogía, 28(1), 8-18.

Ruvalcaba, N. A., Fernández-Berrocal, P. and Salazar, J. G. (2014). Análisis de las relaciones entre la inteligencia emocional y factores asociados a la calidad de vida. Revista Psicología y Salud, 24(2), 245-253.

Sadurní, M. and Rostan, C. (2014). La importancia de las emociones en los períodos sensibles del desarrollo. Infancia y Aprendizaje, 27(1), 105-114.

Salovey, P. and Sluyter, D. J. (Eds.) (1997). Emotional development and emotional intelligence: Educational implications. New York: Basic Books.

Sánchez-Queija, I., Oliva, A. and Parra, A. (2006). Empatía y conducta prosocial durante la adolescencia. Revista de Psicología Social, 21(3), 259-271.

Sotil, A., Escurra, L., Huerta, R., Rosas, M., Campos, E. and Llaños, A. (2008). Efectos de un programa para desarrollar la inteligencia emocional en alumnos del sexto grado de educación primaria. Revista de Investigación en Psicología, 11(2), 55-65.

Tur, A. M., Mestre, V., Samper, P., Malonda, E. and Llorca, A. (2014). Intervención psicosocial en la infancia. In R. González and L. Villanueva (Eds.), Recursos para educar en emociones. De la teoría a la acción (pp. 275-292). Madrid. Pirámide. 
Vallés, A. (2000). S.I.C.L.E. Siendo inteligentes con las emociones. Valencia: Promolibro.

Weissberg, R. P. and O'Brien, M. U. (2004). What works in school-based social and emotional learning programs for positive youth development. The annals of de American Academy of Political and Social Science, 591, 86-97. 
